Articles

\title{
Customer Relationship Management System in Medika Lestari Hospitals
}

\author{
Tugiman $^{1}$, Amat Basri ${ }^{2}$, Benny Daniawan ${ }^{3}$ \\ ${ }^{1,2,3}$ Buddhi Dharma University, Information System, Banten, Indonesia
}

\section{SUBMISSION TRACK}

Recieved: Feb 04, 2020

Final Revision: Feb 19, 2020

Available Online: Feb 26, 2020

\section{KEYWORD}

Customer Relationship Management, Rapid

Application Development (RAD), ISO 9126,

CORRESPONDENCE

E-mail:

${ }^{1}$ Tugiman011@gmail.com,

2ab45r1@gmail.com,

3b3n2y.miracle@gmail.com

\section{A B S T R A C T}

Marketing strategies based on efforts to create relationships between companies and customers are better known as Customer Relationship Management (CRM). CRM is a corporate strategy used to pamper customers so they don't look away. This study wants to find out and improve relations between hospitals and patients. Besides that, by building this system, can it affect customer / patient satisfaction. The quality of information systems is measured using the ISO 9126 model by adapting four characteristics of software quality: Functionality, Reliability, Usability, and Efficiency. The system development method uses the Rapid Application Development (RAD) model. Researchers will conduct system analysis and design using the Unified Model Language (UML), then coding with the PHP programming language and MySQL database, as well as collecting data using a questionnaire, and using the Blackbox Testing model. Based on testing using ISO 9126 the results are functionality (83\%), Reliability (86\%), Usability (87\%), and Efficiency (83\%). Overall the results are $85 \%$ (very good).

\section{INTRODUCTION}

Customer satisfaction is the level of consumer feelings for products or services that arise after comparing between perceptions or impressions, but for services can be measured by performance that can improve service to consumers. If the performance is felt below expectations, the customer will feel disappointed, if the performance meets customer expectations, the customer will feel satisfied, whereas if the performance exceeds expectations, the customer will feel very satisfied. This satisfaction will certainly be felt after the customer concerned consumes the product.

Hospital information needs and customer satisfaction with the information needs mentioned above, as well as the increasingly rapid technological advances, we need an information system that can help build relationships between customers or patients with hospitals.

\section{LITERATURES REVIEW}

Factors affecting business activities: the influence of international economics and 
world competition, technological developments, shorter time limits, and social constraints. Implementing Customer Relationship Management that is supported by information technology is the right solution for a company in providing the best service.

There are 3 (three) frameworks used in Customer Relationship Management (CRM), namely:

1. Operational Customer Relationship Management

is an automated integration process in the activities / business processes in a company that is running The process is often called the front office.

2. Analytical Customer Relationship Management

An analysis process of data in business processes that will later be analyzed and produce information needed for the company, this analysis includes: data mining, needs analysis, market trends and customer behavior.

3. Collaborative Customer Relationship Management

A service collaboration process, which provides facilities for interaction between companies and customers, includes: email, e-communication, or discussion forums.

According to [6], Rapid application Development, as an Alternative to the System Development Life Cycle (SDLC) is a method of developing an information system with a relatively short time. The main purpose of the RAD method is to provide a system that can meet user expectations, but often in developing a system does not involve the users of the system directly.

According to [9], an object-oriented approach is a technique or way of looking at problems and systems. The basic concepts of object-oriented methodology: class, object, method, attribute, abstraction, encapsulation, editing, interface, reusability, generalization and specialization, communication between objects, polymorphism, and package.

According to [7], ISO 9216 standard has been developed in an effort to identify quality attributes for computer software, ISO 9216 Standard basically identifies six quality characteristics as follows: Functionality, Reliability, Usability, Efficiency, Maintainability, Portability.

\section{FRAMEWORK}

This research conceptual framework:

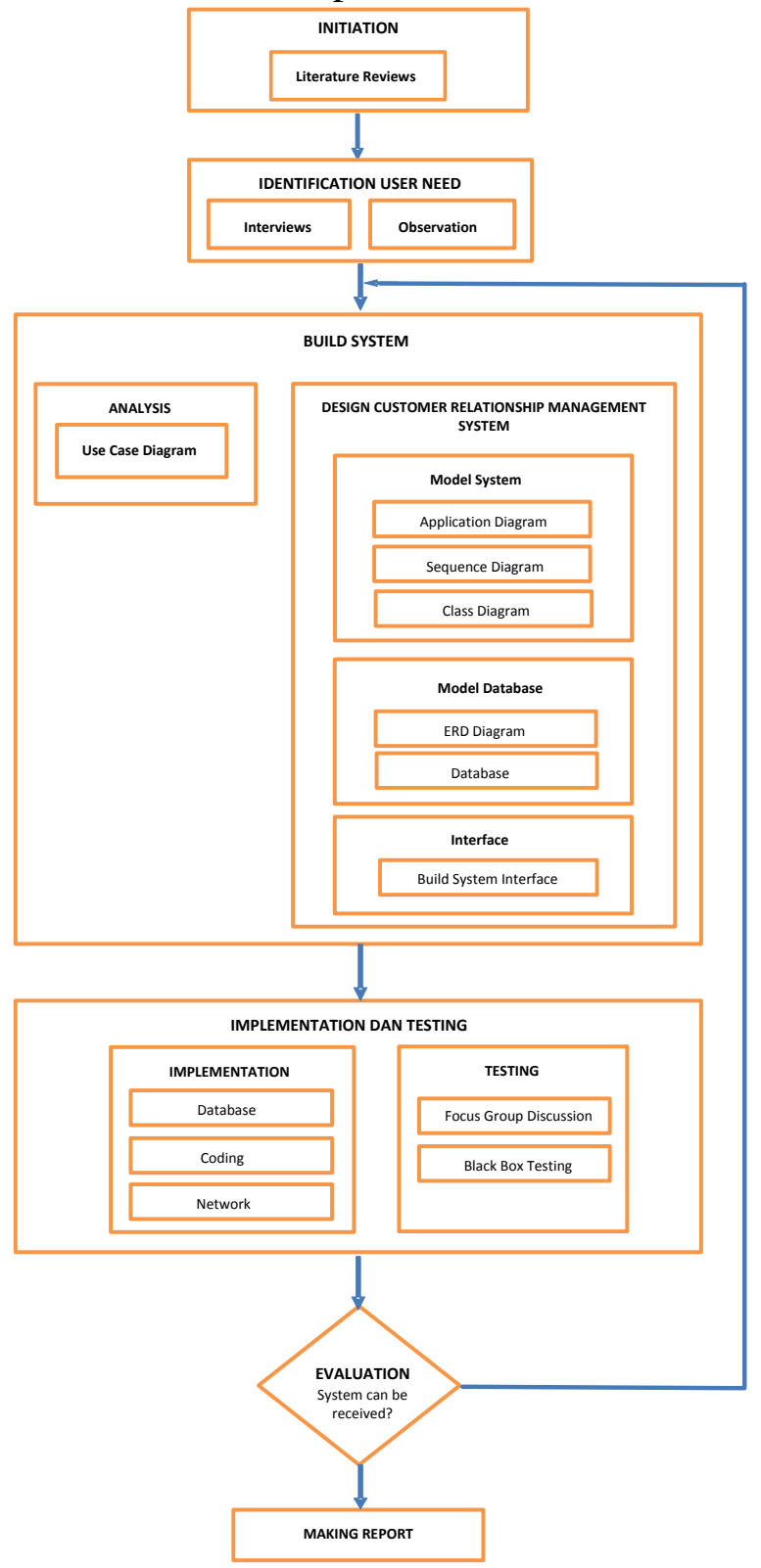

Figure 1. Research Conceptual Framework

1. Researchers conduct technological studies in terms of aspects of the current problems, as well as in terms of institutional aspects and aspects of information technology. 
2. With the system development method Rapid Application Development (RAD). Researchers will conduct system analysis and design with the Unified Model Language, then by coding the PHP programming and MySQL database, and testing the system using FGD, Questionnaire, Blackbox Testing.

3. Display applications are built so that users can input data that will be stored into a MySQL database and at any time the data can be displayed in the form of information with a visual display that is more user friendly and good user experience. This application can be accessed by system users with user level restrictions.

4. Testing with several methods that have been done then concluded whether the system has met the requirements of passing the test based on software adapting ISO 9126.

According to [2], there are several definitions of Focus Group Discussion including the following:

1. The FGD is a data collection technique that was originally used in marketing research. At that time marketing wants to know about opinions about a product and voters' opinions on an issue from the group of people being interviewed at the same time.

2. FGD is one of the in-depth interviews conducted by researchers with a group of people at a time. The groups of people were not interviewed separately, but together in a meeting.

\section{METHODS}

Based on the research objectives included in the type of research development. Development research is a method used to produce a product and test its effectiveness. Research and development methods have often been used in the field of information technology.

Data collection methods by: interviews, observations, literature studies, and documents.
To find out the quality of the software in this study adapted the method used by ISO 9126 by taking four characteristics of software quality, including functionality, reliability, usability, and efficiency.

According to [4], to define a quality, many definitions have been known. International Standard Organization (ISO) defines quality as "the totality of future and characteristics of a product or service that bears on its ability to satisfy specied or implied needs" which means the totality of features and characteristics of products or services that depend on the ability to satisfy needs. The ISO 9126 model is part of the ISO 1900 standard which is the most important standard in the field of quality assurance.

According to [7], the ISO 9216 standard has been developed in an effort to identify quality attributes for computer software, ISO 9216 Standard basically identifies six quality characteristics as follows:

1. Functionality

The ability of the software to provide functions according to user requirements, when used under certain conditions.

2. Reliability

The ability of the software to maintain a certain level of performance, when used under certain conditions. When used in certain conditions.

3. Usability

Soft software capabilities are easy to understand, learn, use, and appeal to users under certain conditions.

4. Efficiency

The ability of the software to provide appropriate and realistic performance of the amount of resources used at the time of the situation.

5. Maintainability

Software's ability to modify. Modifying includes correction, improvement or adaptation to environmental changes, requirements and functional specifications.

6. Portability

The ability of software to be transferred from one environment to another. 
According to [8], testing in the context of software engineering is a series of stages which are implemented sequentially.

This test is to determine the quality of software that is in the hypothesis. The criteria for selecting respondent characteristics as a research sample for testing software is based on the level of user accessing the system.

Testing instruments using data in the form of research results are interpreted into measurements with the aim of producing accurate qualitative data. This study uses a measurement scale is a Likert scale.

This scale was developed by RensisLikert, which is a series of items. Respondents only gave their approval or disapproval of certain items. This scale is intended to measure individual attitudes in the same dimensions and individuals place themselves in the direction of one continuity from the item [1]. Processing of test data using tools in the form of descriptive statistical analysis. The data collected consists of a description of facts that are processed into data. From these data then analyzed in order to obtain a conclusion.Descriptive statistics are statistics used to analyze data by describing or describing data that has been collected as it is without intending to make general conclusions or generalizations [10].

In conducting descriptive statistical analysis in this study required the following steps:

1. Respondents assess each indicator classified into 5 (five) alternative answers. Alternative answer.

2. The collected score is calculated for each variable means the same as the total score of all indicator variables for all study respondents.

3. Then calculate the score of each variable equal to the average of the total scores Then calculate the score of each variable equal to the average of the total score.

4. In response to a description of the research variable, the researcher uses the following range of research criteria:

Actual score

$$
\begin{aligned}
& \text { Total score }= \\
& \text { Ideal score }
\end{aligned}
$$

From the formula above, the actual score is the sum of the answers to the questionnaire that has been submitted, while the ideal score is the sum of the maximum or highest values for all respondents. As an actualization explanation the actual score weights are:

Table1. Test Score Criteria

\begin{tabular}{|c|l|}
\hline$\%$ total score & \multicolumn{1}{|c|}{ Criteria } \\
\hline $20,00 \%-36,00 \%$ & Bad \\
\hline $36,01 \%-52,00 \%$ & Not good \\
\hline $52,01 \%-68,00 \%$ & Enough \\
\hline $68,01 \%-84,00 \%$ & Good \\
\hline $84,01 \%-100 \%$ & Very good \\
\hline
\end{tabular}

Customer Relationship Management is used as a solution in overcoming problems in the business world in the current era of globalization by developing technology and information systems. Science and technology as a basis for opening wider information networks and conveying various types of information. In the business world, one of the most influential systems is how to maintain a good relationship with customers. By implementing Customer Relationship Management supported by information technology, it is the right solution for a company to provide the best service. According to [5], there are 3 (three) frameworks used in Customer Relationship Management (CRM), namely:

1. Operational Customer Relationship Management

Is an automated integration process in the activities / business processes in a company that is running The process is often called the front office.
2. Analytical Customer Relationship Management

An analysis process of data in business processes that will be analyzed and produce information needed for the company, this analysis includes: data mining, needs analysis, market trends and customer behavior.

3. Collaborative Customer Relationship Management

A service collaboration process, which provides facilities for interaction between 
companies and customers, includes: email, e-communication, or discussion forums.

Within this framework the benefits of Customer Relationship Management can be felt and are divided into 3 (three) Among them are:

1. Get a new customer (Aquire), with the ease of accessing the stages of the process and the existence of new innovations, the customer will be interested and be able to attract new customers.

2. Increasing Customer Value (Enhance), providing the best service to customers has an impact on creating harmonious relationships.

3. Retain Customers (Retain), is an effort to get loyalty by trying to meet all customer needs

The conclusions obtained in implementing Customer Relationship management are encouraging customer loyalty, reducing costs incurred, increasing operational efficiency and increasing opinions.

The system development method uses Rapid Application Development (RAD). According to [6], Rapid application Development, as one of the Alternatives to the System Development Life Cycle (SDLC) is a method of developing a piece of information with a relatively short time. The main purpose of the RAD method is to provide a system that can meet user expectations, but often in developing a system does not involve the users of the system directly.

The strategy of developing or developing an object-oriented system is to organize and integrate a software system as a collection of objects containing data and operations that are implemented in a way that the system is built through a systematic object approach.

According to [3], Sequence diagrams depict objects that exist in use cases and massage that runs in a use case. Sequence diagrams also describe objects and their relationships including the chronology (sequence) of logical changes after receiving a message.

According to [9], Rapid Application Development (RAD) is a model of the process of software development that is non- critical especially because the time required is relatively short. The team must be able to understand software requirements and must be limited in scope so that the team can complete the creation of software in a short time.

The RAD model divides the development team into several teams to work on several components, each work team can be done in parallel. The short-cut RAD model includes the following phases:

1. Business Modeling

Modeling is done to model business functions to find out what information must be made, who has to make information, how the flow of information is related to what information.

\section{Data Modeling}

Model what data is needed based on business modeling and defining its attributes along with their relationships with other data.

3. Process modeling

Implement business functions that have been defined in relation to defining data. The processing image was created to add, modify, delete or retrieve data objects.

4. Making the application Implement process and data modeling into a program. The RAD model strongly recommends the use of existing components if possible.

5. Testing and replacement

Test the components that are made, if it has been tested the component development team can move to develop the next component.

\section{SYSTEM PLANNING}

The system design can be described through:

a. Use Case: divided into master use case, use transaction, and use case report. In this report the author gives an example of 1 use casereport. 


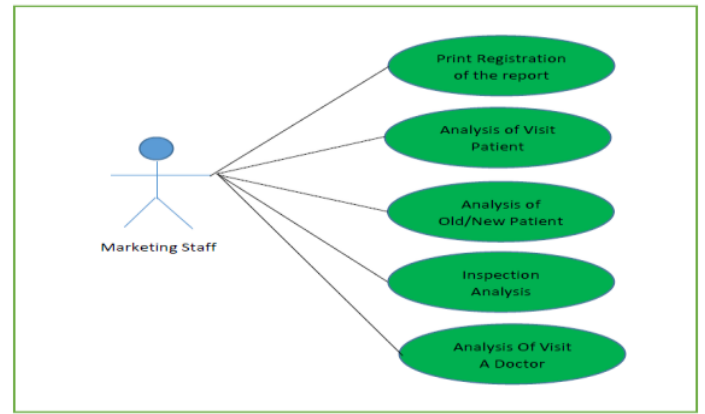

Figure 2 : use case report

b. Activity Diagram: divided into activity diagrams of registration, inspection, payment, and reports. The following is the report activity:

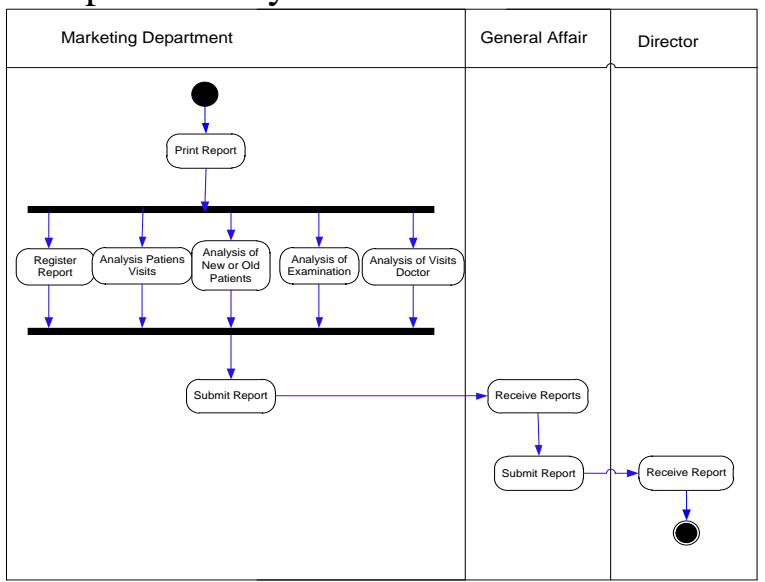

Figure 3 :Activity Diagram Report

c. Sequence diagrams consist of patient data entry, polyclinic data entry, payment data entry, doctor data entry, doctor practice schedule data entry, patient registration data entry, examination data entry, payment data entry, and report sequence diagram. Following is the sequence report diagram:



Figure 4 : Sequence Diagram Report

\section{DISCUSSION}

\section{System Testing and Implementation}

System testing uses the blackbox testing method and uses ISO 9126. The following results are:

\section{Functionality}

Table2. Test Result Functionality

\begin{tabular}{|c|c|c|c|c|c|c|c|c|c|c|}
\hline \multirow{3}{*}{$\begin{array}{l}\text { Answer } \\
\text { Criteria }\end{array}$} & \multirow{3}{*}{ Weight } & \multicolumn{8}{|c|}{ Functionality } & \multirow{3}{*}{ Total } \\
\hline & & \multicolumn{2}{|c|}{ Suitablity } & \multicolumn{2}{|c|}{ Compliance } & \multicolumn{2}{|c|}{ Accuracy } & \multicolumn{2}{|c|}{$\begin{array}{c}\text { Interopera- } \\
\text { bility }\end{array}$} & \\
\hline & & 1 & 2 & 3 & 4 & 5 & 6 & 7 & 8 & \\
\hline SS & 5 & 8 & 6 & 12 & 9 & 16 & 13 & 9 & 7 & 400 \\
\hline $\mathrm{S}$ & 4 & 12 & 13 & 11 & 15 & 10 & 12 & 17 & 9 & 396 \\
\hline $\mathrm{R}$ & 3 & 3 & 2 & 3 & 2 & 0 & 1 & 0 & 6 & 51 \\
\hline TS & 2 & 2 & 3 & 0 & 0 & 0 & 0 & 0 & 3 & 16 \\
\hline STS & 1 & 1 & 2 & 0 & 0 & 0 & 0 & 0 & 1 & 4 \\
\hline \multicolumn{2}{|c|}{ Total Recipe } & 26 & 26 & 26 & 26 & 26 & 26 & 26 & 26 & \\
\hline \multicolumn{2}{|c|}{ Score actual } & 102 & 96 & 113 & 111 & 120 & 116 & 113 & 96 & 867 \\
\hline \multicolumn{2}{|c|}{ Score ideal } & 130 & 130 & 130 & 130 & 130 & 130 & 130 & 130 & 1040 \\
\hline
\end{tabular}

Note :

$\mathrm{SS}=$ Strongly Agree, $\mathrm{S}=$ Agree, $\mathrm{R}=$ Doubt , $\mathrm{TS}=$ Disagree, $\mathrm{STS}=$ Strongly Disagree

\section{Reliablity}

Table 3. Test Result Reliability

\begin{tabular}{|l|c|c|c|c|c|c|c|}
\hline \multirow{2}{*}{$\begin{array}{l}\text { Answer } \\
\text { Criteria }\end{array}$} & \multirow{5}{*}{ Weight } & \multicolumn{5}{|c|}{ Reliability } & \multirow{2}{*}{ Total } \\
\cline { 3 - 7 } & & $\mathbf{9}$ & $\mathbf{1 0}$ & $\mathbf{1 1}$ & $\mathbf{1 2}$ & $\mathbf{1 3}$ & \\
\cline { 3 - 8 } & 5 & 15 & 12 & 8 & 16 & 11 & 62 \\
\hline \hline SS & 4 & 10 & 9 & 13 & 8 & 12 & 52 \\
\hline S & 3 & 1 & 3 & 4 & 2 & 1 & 11 \\
\hline R & 2 & 0 & 2 & 0 & 0 & 2 & 4 \\
\hline TS & 1 & 0 & 0 & 1 & 0 & 0 & 1 \\
\hline STS & 26 & 26 & 26 & 26 & 26 & \\
\hline Total Recipe & 118 & 109 & 105 & 118 & 110 & 560 \\
\hline Score actual & 130 & 130 & 130 & 130 & 130 & 650 \\
\hline Score ideal & & & & & & \\
\hline
\end{tabular}

Note:

$\mathrm{SS}=$ Strongly Agree, $\mathrm{S}=$ Agree, $\mathrm{R}=$ Doubt, TS=Disagree, $S T S=$ Strongly Disagree 


\section{Usability}

Table 4. Test Result Usability

\begin{tabular}{|c|c|c|c|c|c|c|c|c|c|c|}
\hline \multirow{3}{*}{$\begin{array}{c}\text { Anwer } \\
\text { Criteria }\end{array}$} & \multirow{3}{*}{ Weigh } & \multicolumn{8}{|c|}{ Usability } & \multirow{3}{*}{ Total } \\
\hline & & \multicolumn{2}{|c|}{ Understandbility } & \multicolumn{2}{|c|}{ learnability } & \multicolumn{2}{|c|}{ Operability } & \multicolumn{2}{|c|}{ Attractivness } & \\
\hline & & 14 & 15 & 16 & 17 & 18 & 19 & 20 & 21 & \\
\hline SS & 5 & 16 & 12 & 13 & 9 & 13 & 15 & 8 & 6 & 92 \\
\hline$S$ & 4 & 10 & 10 & 9 & 16 & 10 & 11 & 14 & 17 & 97 \\
\hline $\mathrm{R}$ & 3 & 0 & 3 & 4 & 1 & 3 & 0 & 3 & 3 & 17 \\
\hline TS & 2 & 0 & 1 & 0 & 0 & 0 & 0 & 1 & 0 & 2 \\
\hline STS & 1 & 0 & 0 & 0 & 0 & 0 & 0 & 0 & 0 & 0 \\
\hline \multicolumn{2}{|c|}{ Total Recipe } & 26 & 26 & 26 & 26 & 26 & 26 & 26 & 26 & \\
\hline \multicolumn{2}{|c|}{ Score actual } & 120 & 111 & 113 & 112 & 114 & 119 & 107 & 107 & 903 \\
\hline \multicolumn{2}{|c|}{ Score ideal } & 130 & 130 & 130 & 130 & 130 & 130 & 130 & 130 & 1040 \\
\hline
\end{tabular}

Note:

$\mathrm{SS}=$ Strongly Agree, $\mathrm{S}=$ Agree, $\mathrm{R}=$ Doubt, $\mathrm{TS}=$ Disagree, $\mathrm{STS}=$ Strongly Disagree

\section{Efficiency}

Table5. Test Result Efficiency

\begin{tabular}{|c|c|c|c|c|c|}
\hline \multirow{3}{*}{$\begin{array}{l}\text { Anwer } \\
\text { Criteria }\end{array}$} & \multirow{3}{*}{ Weight } & \multicolumn{3}{|c|}{ Efficiency } & \multirow{3}{*}{ Total } \\
\hline & & \multicolumn{2}{|c|}{$\begin{array}{c}\text { Time } \\
\text { Behavior }\end{array}$} & \multirow{2}{*}{$\begin{array}{c}\text { Resource } \\
\text { Behavior }\end{array}$} & \\
\hline & & 22 & 23 & & \\
\hline SS & 5 & 10 & 5 & 8 & 23 \\
\hline S & 4 & 13 & 17 & 14 & 44 \\
\hline $\mathrm{R}$ & 3 & 3 & 4 & 3 & 10 \\
\hline TS & 2 & 0 & 0 & 1 & 1 \\
\hline STS & 1 & 0 & 0 & 0 & 0 \\
\hline \multicolumn{2}{|c|}{ Total Recipe } & 26 & 26 & 26 & \\
\hline \multicolumn{2}{|c|}{ Score actual } & 111 & 105 & 107 & 323 \\
\hline \multicolumn{2}{|c|}{ Score ideal } & 130 & 130 & 130 & 390 \\
\hline
\end{tabular}

Note:

$\mathrm{SS}=$ Strongly Agree, $\mathrm{S}=$ Agree, $\mathrm{R}=$ Doubt, TS=Disagree, $S T S=$ Strongly Disagree

Overall testing results using ISO 9126 are:

Table6. Overall Testing Results

\begin{tabular}{|c|c|c|c|c|}
\hline Aspect & $\begin{array}{c}\text { Score } \\
\text { actual }\end{array}$ & $\begin{array}{c}\text { Score } \\
\text { ideal }\end{array}$ & $\begin{array}{c}\% \text { Score } \\
\text { actual }\end{array}$ & Criteria \\
\hline \hline Functionality & 867 & 1040 & $83 \%$ & Good \\
\hline
\end{tabular}

\begin{tabular}{|l|c|c|c|c|} 
Reliability & 560 & 650 & $86 \%$ & Very good \\
\hline Usability & 903 & 1040 & $87 \%$ & Very good \\
\hline Efficiency & 323 & 390 & $83 \%$ & Good \\
\hline Total & 2653 & 3120 & $85 \%$ & Very good \\
\hline
\end{tabular}

The results of testing using a blackbox and ISO 9126 are:

Tabel7. HasilPengujianBlackbox dan ISO 9126

\begin{tabular}{|c|l|c|c|}
\hline No & \multicolumn{1}{|c|}{ Testing } & Success & Result \\
\hline 1 & ISO 9126 & $85 \%$ & Very good \\
\hline 2 & Blackbox testing & $91.9 \%$ & Very good \\
\hline
\end{tabular}

Based on the results of software testing that is the system of performance and quality of hospitals that researchers do, the third hypothesis regarding system testing by adapting the four criteria of ISO 9126 achieves expectations of "very good"

\section{CONCLUSION}

Based on the problem, literature study, research review, research object review, and research process models in the development of Customer Relationship Management information systems that the author did at the Medika Lestari Hospital, it can be concluded as follows:

1. Research conducted by researchers aims to develop Hospital Customer Relationship Management information systems using the Managed Services approach. System analysis is done using an object-oriented approach using UML, while applications are developed using PHP. The database used in the development of this system uses MySQL.

2. The quality of the information system is measured using the ISO 9126 model by adapting the characteristics of software quality: functionality, reliability, usability, and efficiency. The system development method uses the Rapid Application Development (RAD) model. Researchers will analyze and design the system using the Unified Model Language (UML), then by coding the PHP programming and MySQL database, and collecting data 
using a questionnaire, and testing the system using the Blackbox Testing model. Based on testing using ISO 9126 the results are functionality (83\%), reliability $(86 \%)$, usability $87 \%)$, and efficiency $(83 \%)$. Overall the results are $85 \%$ (very good).

\section{ACKNOWLEDGEMENT}

The authors would like to express our gratitude for the support provided by Faculty of Science and technology. The financial assistance from Research, Publication and Community Service Department Buddhi Dharma University is also greatly acknowledged.

\section{REFERENCES}

[1] A Muri Yusuf, Metode Penelitian Kuantitatif, Kualitatif, dan Penelitian Gabungan, 2014, Prenada media Group, Jakarta.

[2] Afrizal, 2014, Metode Penelitian Kualitatif Supaya mendukung Penggunaan Penelitian Kualitatif Dalam Berbagai Disiplin Ilmu, Raja Grafndo Persada

[3] Dennis, Alan, at.al. System Analisys and Design with UML-3 ${ }^{\text {rd }}$ Edition. John Wiley \& Sons, Inc, 2009.

[4] Galang, A.D, dkk. 2014. Pengukuran Kualitas untuk aplikasi Permainan pada Perangkat bergerak berdasarkan ISO9126. ISSN 2085-4579

[5] Kadir, Abdul 2014. Pengenalan sistem Informasi Edisi Revisi. Jogjakarta : Penerbit Andi Yogyakarta.

[6] Neortjahyana, Agustinus, 2002. Studi Analisis Rapid Development Sebagai salah satu Alternatif Metode pengembangan perangkat lunak. Jurnal Informatika, Vol 3, No. 2.

[7] Nofiyani, Agus U.H 2015. Jurnal Prototipe Sistem Electronic Customer Relation Management (E-CRM) untuk mendukung industry Manufactur pada PT. Argo PantesTbk. ISSN Z: 2407-3911, Volume II No. 1.

[8] Pressman, Rogers S. Software Enginering : A Practitioner's Approach $7^{\text {th }}$ ed. Translated by Nugroho, Adi et.al. Yogyakarta :Andi 2012.

[9] Rosa A.S. Shalahudin M. 2013. Rekayasa Perangkat Lunak Terstruktur dan berorientasi Objek, Bandung : Infromatika Bandung

[10] Sudaryono, 2015 Metodelogi riset di bidang IT, Yogyakarta, Andi

\section{BIOGRAPHY}

Tugiman, Graduated in the Information Technology Study Program (S1) in 2014, continued his Masters in Information Systems in 2014 and graduated in 2016. He is currently a Lecturer Information Systems Study Program at Buddhi Dharma University.

AmatBasri, Graduated in the Information Technology Study Program (S1) in 2002, continued his Masters in Information Systems in 2014 and graduated in 2016. Currently, He is currently a lecturer Information Systems Study program at Buddhi Dharma university

Benny Daniawan, Graduated in the Information Technology Study Program (S1) in 2011, continued his Masters in Information Systems in 2014 and graduated in 2016. He is currently a Lecturer Information Systems Study Program at Buddhi Dharma University. 